\title{
Social klasse og tidlig tilbagetrækning fra arbejdsmarkedet: Et livsforløbsperspektiv
}

\author{
Jeevitha Yogachandiran Qvist
}

I den eksisterende forskning om sammenhængen mellem social klasse og tidlig tilbagetrækning fra arbejdsmarkedet har livsforløbsperspektivet været et empirisk underbelyst emne. Denne artikel undersøger derfor først sammenhængen mellem stilling på arbejdsmarkedet (social klasse), og hvornår man trækker sig tilbage fra arbejdsmarkedet, herunder om forskellene i tidlig tilbagetrækning fra arbejdsmarkedet mellem sociale klasser bliver større over livsforløbet. Dernæst undersøger artiklen, hvad arbejdsløshed og dårligt helbred over livsforløbet har af betydning for klasseforskellene i risikoen for tidligere tilbagetrækning fra arbejdsmarkedet. Baseret på registerbaseret forløbsanalyse af personer født i 1951 og Danmarks Statistiks fagklassifikation (DISCO-koder) til klasseinddeling, viser resultaterne, at ikke-faglærte og faglærte (personer der tilhører arbejderklassen) trækker sig markant tidligere tilbage end topledere og specialiserede lønmodtagere (personer der tilhører den højere serviceklasse), og klasseforskellene bliver signifikant større over livsforløbet. Resultaterne viser også, at arbejdsløshed og dårligt helbred har langsigtede konsekvenser for tidligere tilbagetrækning fra arbejdsmarkedet, og at klasseforskellene i tidligere tilbagetrækning fra arbejdsmarkedet over livsforløbet bliver mindre, når man tager højde for de kontemporære effekter af arbejdsløshed og dårligt helbred.

Nøgleord: Tidlig tilbagetrækning fra arbejdsmarkedet, social klasse, livsforløb, arbejdsløshed, helbred

\section{Indledning}

I studier om seniorers tilbagetrækningsmønstre er der bred enighed om, at der eksisterer en social ulighed i tidspunktet for tilbagetrækning fra arbejdsmarkedet. Det er personer, der tilhører arbejderklassen, der trækker sig tidligere (og ufrivilligt) tilbage, fordi de oftest bliver 'pushet' ud af arbejdsmarkedet (Blossfeld, Buchholz \& Kurz, 2011; Leinonen, Chandola, Laaksonen, \& Martikainen, 2018; Radl, 2013). Push faktorer er forhold, der bevirker, at det enkelte individ udstødes fra arbejdsmarkedet, og derfor forlader arbejdsmarkedet før tid. Dette inkluderer bl.a. svækkelse af helbred, arbejdsløshed, ringe arbejdsvilkår og diskrimination og står således i kontrast til såkaldte 'pull' og 'jump' faktorer, der forklarer tidligere tilbagetrækning med økonomiske incitamenter og ønsket om mere tid til familie og fritid (Jensen, 2011). Sammenhængen mellem push faktorer og tidligere tilbagetrækning har den eksiste- 
rende forskning primært afdækket empirisk ved at undersøge de kontemporære faktorer, der påvirker tidligere tilbagetrækning. Med kontemporære faktorer menes her faktorer, der måler de ældres livs- og arbejdssituation umiddelbart inden eller samtidig med at tilbagetrækning finder sted (De Preter, Van Looy \& Mortelmans, 2013; Lund \& Villadsen, 2005; Solinge \& Henkens, 2018; Thorsen, Jensen \& Bjørner, 2016). Imidlertid er der stærke grunde til at forvente, at også ældres livs- og arbejdssituation fra tidligt og midt i livet har langsigtede og utilsigtede konsekvenser senere i livet og dermed også for risikoen for tidligere tilbagetrækning. Dette er en af de centrale antagelser i teorier om aldring og livsforløb (O’Rand \& Henretta, 1999).

Denne artikel tager udgangspunkt i teorien om kumulativ stratifikation, som antager at forskelle mellem ressourcestærke- og svage grupper i samfundet akkumuleres, og derfor bliver forskellene større over livsforløbet (O'Rand \& Henretta, 1999). Dette skyldes, at personer med mange økonomiske, sociale og kulturelle ressourcer vil akkumulere disse ressourcer gennem livsforløbet, hvilket vil resultere i bedre livsbetingelser i de senere år. Omvendt vil personer med færre ressourcer akkumulere dårligere livsbetingelser, hvilket således kan påvirke risikoen for tidligere tilbagetrækning. Flere forskere har påpeget vigtigheden i at undersøge tilbagetrækning fra arbejdsmarkedet i et livsforløbsperspektiv, da mange af de faktorer, der påvirker tidligere tilbagetrækning, går langt tilbage i ens tidligere arbejdsliv. At gå fra arbejde og ind i en tilværelse som (tidlig) pensionist kan ikke ses som en isoleret overgang, men skal ses som et resultat af ens livsforløb (Kohli \& Rein, 1991; Wang \& Shultz, 2010). Eksisterende forskning har vist, at arbejdsløshed og dårligt helbred er to af de mest dominerende push faktorer, der leder til tidligere tilbagetrækning (Edge, Cooper \& Coffey, 2017; Raymo, Warren, Sweeney, Hauser \& Ho, 2011; Visser,
Gesthuizen, Kraaykamp \& Wolbers, 2016), og samtidig har den eksisterende forskning vist, at arbejdsløshed og dårligt helbred fra tidligere i livet har langsigtede og utilsigtede konsekvenser senere i livet (Birkelund, Heggebø \& Rogstad, 2016; DiPrete \& Eirich, 2006; Dupre, 2008; Ferraro \& Kelley-Moore, 2003). Når personer, der tilhører arbejderklassen, har højere risiko for at trække sig tidligere tilbage fra arbejdsmarkedet end andre socialklasser, kan det derfor skyldes, at de allerede tidligt $\mathrm{i}$ arbejdslivet har oplevet arbejdsløshed eller fået et dårligt helbred, som således akkumuleres gennem arbejdslivet, og derfor resulterer i tidligere tilbagetrækning. Et sådant livsforløbsperspektiv på tidlig tilbagetrækning har imidlertid været empirisk underbelyst og særligt underbelyst i kombination med et socialt ulighedsperspektiv. Derfor sætter denne artikel fokus på social ulighed, livsforløb og tidlig tilbagetrækning fra arbejdsmarkedet. Med afsæt i teorien om kumulativ stratifikation undersøger artiklen følgende spørgsmål: 1) Bliver forskelle i tidligere tilbagetraekning mellem personer, der tilhører henholdsvis arbejderklassen og den højere serviceklasse større eller mindre jo toettere grupperne noermer sig folkepensionsalderen? 2) Hvad er de langsigtede og kontemporaere effekter af arbejdsløshed og dårligt helbred på risikoen for tidligere tilbagetraekning, og kan forskelle i arbejdsløshed og helbred forklare gabet i tidligere tilbagetraekning imellem personer, der tilhører henholdsvis arbejderklassen og den højere serviceklasse?

De få studier, der har undersøgt tidligere tilbagetrækning fra arbejdsmarkedet i et livsforløbsperspektiv, har primært anvendt et retrospektivt design, hvor respondenterne gengiver tidligere historik omkring arbejdsløshed, helbred mm. i surveys (Damman, Henkens \& Kalmijn, 2011; Raymo et al., 2011; Visser et al., 2016). Imidlertid er sådanne selvrapporterede oplysninger forbundet med en række svagheder. For det første er der risiko for, at respondenter besvarer spørgsmål om 
tidligere hændelser set i lyset af hændelser, der er sket efter. For det andet kan respondenter glemme, hvornår hændelser er fundet sted (de Vaus, 2001), hvilket i særlig grad kan forekomme, når der er tale om mindre favorable hændelser som fx arbejdsløshed (Jacobs, 2002). Som et led i at imødekomme dette problem, tager denne empiriske analyse sit afsæt i registerdata, hvor sådanne problemer ikke eksisterer. Undersøgelsespopulationen består af kohorten født i 1951. Deres arbejdsløshed og helbred måles tilbage i tid fra 1995, dvs. fra kohorten er 43 år og dermed befinder sig midt i arbejdslivet, og alle efterfølgende år frem til de trækker sig tilbage eller runder de 65 år i 2017. Afgrænsningen til de 43 år skyldes tilgængeligheden af data.

Til at måle social klasse anvendes Erikson Goldthorpe Portocarero (EGP) klasseskema (Erikson \& Goldthorpe, 1992). Skemaet er særligt velegnet til at studere tidlig tilbagetrækning fra arbejdsmarkedet, da klasseinddelingen tager udgangspunkt i individernes stillingskategorier på arbejdsmarkedet og kombinerer denne information med ansættelsesforhold, industri og færdigheder. I den øverste del af klasseinddelingen findes den højere serviceklasse, hvis medlemmer primært består af topledere, ejere af større virksomheder samt specialiserede lønmodtagere som fx ingeniører. Fælles for disse grupper er, at de har en specialiseret viden og derfor også en høj grad af autonomi og sikkerhed i deres ansættelse i modsætning til arbejderklassen, hvis medlemmer primært består af personer med manuelt faglært arbejde, fx bygningsarbejde og ikke-faglært arbejde fx rengørings- og køkkenarbejde. Det er disse to ydergrupper, som artiklen primært har fokus på. Imellem de to ydergrupper findes også den lavere serviceklasse, der i stort omfang inkluderer lønmodtagere med færdigheder på mellemniveau, fx folkeskolelærere. Derudover findes også rutine, ikke-manuelle arbejdere, hvis arbejde typisk ikke kræver specialiserede færdigheder, men som samtidig er svær at monitorere for en arbejdsgiver. Dette inkluderer fx kontorarbejdere. Endeligt findes også gruppen af de selvstoendige, der inkluderer forskellige typer af erhverv, men i modsætning til lønmodtagere, har de typisk mere fleksibilitet og frihed i deres arbejde (Erikson \& Goldthorpe, 1992). EGP-klasseskemaet er internationalt sammenligneligt og har været anvendt i eksisterende forskning om arbejdsmarkedsforhold og helbred (Hansen \& Ingebrigtsen, 2008; Krokstad, Johnsen \& Westin, 2002; Radl, 2013; Visser et al., 2016).

\section{Teoretisk baggrund: Social klasse og tidlig tilbagetrækning over livsforløbet}

I litteraturen om aldring og livsforløb findes forskellige teorier om, hvordan sammenhængen mellem aldring og ulighed forløber sig over livet.

Den mest anvendte teori om ulighed over livsforløbet refererer til 'kumulativ stratifikation'. Teorien antager, at uligheder imellem forskellige grupper i samfundet vil blive større over livsforløbet (O'Rand \& Henretta, 1999). Denne antagelse har klare ligheder til den såkaldte Matthæuseffekt, der henviser til, at dem der i forvejen har, får mere, og dem der ikke i forvejen har, bliver der taget fra (Lynch \& Brown, 2011). Således vil personer med mange ressourcer akkumulere disse ressourcer gennem livet, hvilket medfører, at de har en række bedre livsbetingelser gennem resten af livet. Omvendt vil personer, der ikke har mange ressourcer, ikke kunne høste frugten heraf, og de vil derfor være mindre godt stillet sammenlignet med de ressourcestærke grupper over livsforløbet. Der er flere grunde til at antage, at dette perspektiv også kan genfindes i uligheden i seniorers tilbagetrækningsmønstre. Selvom der allerede eksisterer forskelle tidligt $\mathrm{i}$ arbejdslivet imellem arbejderklassen og den højere serviceklasse, er der grund til 
at antage, at mentalt og fysisk belastende arbejde endnu ikke spiller en væsentlig rolle for tilbagetrækningstidspunktet fra arbejdsmarkedet. Tilsvarende er $\mathrm{fx}$ forskelle $\mathrm{i}$ indkomst heller ikke lige så udtalt i starten af arbejdslivet. Som tiden går, vil personer der tilhører arbejderklassen tidligere i livet blive mere eksponeret for de såkaldte push faktorer, som oftere leder til tidligere (og ufrivillig) tilbagetrækning fra arbejdsmarkedet. Derfor kan man forvente, at forskelle i tidlig tilbagetrækning mellem personer, der tilhører arbejderklassen og den højere serviceklasse, vil stige over livsforløbet, dvs. frem til de nærmer sig folkepensionsalderen. Der findes også konkurrerende teorier til 'kumulativ stratifikation' bl.a. 'udlignende aldring', der antager, at uligheden over livsforløbet bliver mindre, hvilket skyldes biologisk aldring, samt reformer der har til formål at omfordele ressourcer imellem grupper (Lynch \& Brown, 2011). Overføres denne teori til ulighed i seniorers tilbagetrækningsmønstre, vil dette betyde, at gabet i tidlig tilbagetrækning imellem personer, der tilhører arbejderklassen og den højere serviceklasse, mindskes, jo tættere de nærmer sig folkepensionsalderen. Dette vil, ifølge teorien, skyldes, at alle individer uanset klasseposition bliver ældre som årene går, og helbred og arbejdsevne vil derfor også blive svækket. Tilsvarende vil fx en (relativ) universel ordning som efterløn betyde, at alle personer uanset klasseposition har mulighed for at trække sig tidligt tilbage. Endeligt kan det også antages, at forskellene i tidlig tilbagetrækning imellem arbejderklassen og den højere serviceklasse ikke ændrer sig over tid, men vedbliver med at være konstant, jo tættere de nærmer sig folkepensionsalderen.

I denne artikel antages det, at uligheden i seniorers tidlige tilbagetrækningsmønstre bliver større over livsforløbet, hvilket skyldes, at personer, der tilhører arbejderklassen tidligere i livet og i højere grad, bliver eksponeret for push faktorer, der leder til tidligere til- bagetrækning sammenlignet med personer, der tilhører den højere serviceklasse. Til at forklare hvorfor disse klasseforskelle stiger over livsforløbet, inddrages tidligere arbejdsløshed og helbred som forklaringer herpå.

Eksisterende forskning viser, at arbejdsløshed tidligt i livet har en række langsigtede og utilsigtede konsekvenser for det senere arbejdsliv (Gangl, 2006; Nilsen \& Reiso, 2011). Bl.a. påpeger forskningen, at tidligere arbejdsløshed er med til at reducere individets human kapital og individets psykologiske parathed til at komme i arbejde, samt at individet blive mindre attraktiv for fremtidige arbejdsgivere (DiPrete \& Eirich, 2006). Idet personer, der tilhører arbejderklassen, er overrepræsenteret i den industrielle sektor, har ringere arbejdsvilkår og mere usikkerhed i deres ansættelse, er de også i større risiko for at opleve arbejdsløshed (Visser et al., 2016). Derfor kan det forventes, at deres arbejdsløshedshistorik medfører, at de ikke kan fastholde en stabil position på arbejdsmarkedet og derfor trækker sig tidligere tilbage fra arbejdsmarkedet.

Der er også stærk grund til at tro, at et allerede dårligt helbred midt $i$ livet har betydning for tidligere tilbagetrækning. Eksisterende forskning har bl.a. vist, at dårligt helbred i barndommen øger risikoen for at få kroniske sygdomme senere i livet (Blackwell, Hayward \& Crimmins, 2001). Derfor kan det forventes, at et dårligt helbred midt $\mathrm{i}$ arbejdslivet tilsvarende medfører tidligere tilbagetrækning fra arbejdsmarkedet. Personer, der tilhører arbejderklassen, er mere udsat for at få et dårligt helbred end personer, der tilhører den højere serviceklasse, fx har personer med manuelt arbejde startet deres arbejdsliv tidligt og bliver i kraft af deres arbejde tidligere i livet konfronteret med fysisk og andet belastende arbejde, der kan forværre helbredet hurtigere, end det er tilfældet for personer, der tilhører den højere serviceklasse. Tilsvarende er der også andre 
mekanismer, der forklarer ulighed i helbred, fx forskelle i livsstile som påvirker helbredet gennem livsforløbet (Bartley, 2004). Endeligt kan også stigende forskelle i indkomst lede til forskellige måder at forebygge dårligt helbred på. Derfor kan det forventes, at dårligt helbred tidligt i livet kan forklare noget af klasseforskellene i tidlig tilbagetrækning.

\section{Data og metode}

Den empiriske analyse tager sit afsæt i registerdata og består af kohorten født i 1951. Denne kohorte følges fra de er 50 år, og frem til de runder 65 år i 2017, som er den officielle folkepensionsalder for kohorten. Analysen inddrager individoplysninger om arbejdsløshed og helbred samt øvrige demografiske og socioøkonomiske karakteristika for de i alt 15 år. Derudover inddrager analysen oplysninger om arbejdsløshed og helbred tilbage i tid, dvs. fra individerne er mellem 43 og 49 år. I analysen indgår 53.252 personer fordelt på 637.063 person-år.

\section{Variabler}

Den afhængige variabel måler tidlig tilbagetrækning fra arbejdsmarkedet. Denne variabel er hentet fra registret om arbejdsstyrkestatistik, der indeholder oplysninger om individers primære arbejdsmarkedsstatus for hvert år. Personerne i analysen er defineret som tidligt tilbagetrukne, hvis de overgår til førtidspension, flexydelse, efterløn eller anden tidlig pension, eller hvis de bliver arbejdsløse målt fra alderen 50 år, og forbliver det frem til de runder 65 år. Personer, der ikke har trukket sig tilbage fra arbejdsmarkedet inden de runder 65 år, som vandrer ud af landet eller dør undervejs i forløbet, bliver højre censureret.

EGP klasseinddeling kodes ud fra de såkaldte DISCO-koder, som er den officielle danske version af den internationale fag- klassifikation ISCO (International Standard Classification of Occupations) (Ganzeboom \& Treiman, 1996). I analysen skelnes imellem 1: Højere serviceklasse 2: Lavere serviceklasse 3: Selvstændige 4: Rutine, ikke-manuelle arbejdere, 5: Faglærte manuelle arbejdere og 6: Ikke-faglærte manuelle arbejdere. Klasseposition måles i det år, kohorten fylder 43 år, som er den tidligste alder, hvor information om arbejdsløshed og helbred indgår i analysen. Personer der ikke har en DISCO-kode er ekskluderet fra analysen. Dette udgør ca. $4 \%$ og består primært af personer, der var arbejdsløse i alderen 43 år.

Arbejdsløshed og helbred er, udover social klasse, de primære variabler af interesse. Fælles for disse variable er, at de både måles midt i livet, som dækker over alderen 43-49 år, og senere i livet som dækker over alderen 50 år og frem til tilbagetrækning/højre censurering. Denne sondring laves for at skelne mellem langsigtede effekter af arbejdsløshed og helbred, der er målt midt i arbejdslivet kontra kontemporære effekter af arbejdsløshed og helbred, der er målt senere $\mathrm{i}$ arbejdslivet og dermed samtidig med tilbagetrækning.

Arbejdsløshed er konstrueret ud fra en variabel, der måler i hvor stor en andel af hvert år, en person har været ledig. Ledighedsgraden er beregnet som antallet af ledige timer i forhold til antallet af (mulige) arbejdstimer. Den angives i promille, så en ledighedsgrad på 1000 angiver, at den pågældende person har været ledig hele året, mens en ledighedsgrad på 0 angiver, at personen har været $\mathrm{i}$ arbejde hele året. Arbejdsløshed midt i livet måles som summen af ledighedsgrader fra alderen 43-49 år, imens arbejdsløshed senere i livet måles som ledighedsgrader for hvert år fra 50 år og til alderen for tidlig tilbagetrækning.

Helbred måles ud fra en række forskellige indikatorer, der dels stammer fra oplysninger om diagnoser fra Landspatientsregistret og dels ud fra oplysninger om kontakter til læge fra Sygesikringsregistret. Første indikator på 
helbred er Charlson komorbiditets indeks, der er et internationalt validt mål for sygelighed. Indekset er et vægtet indeks af 19 sygdomsgrupper, som alle har en negativ indvirkning på individers helbred (Charlson, Pompei, Ales \& MacKenzie, 1987). Disse sygdomsgrupper inkluderer bl.a. blodprop i hjertet, lungesygdomme, gigtsygdomme, diabetes, nyresygdom, leversygdom og kræft. Hver sygdomsgruppe tilskrives en vægt, hvor summen af vægtene angiver komorbiditetsniveauet. Variablen er i denne analyse opdelt i tre kategorier, 0 : ingen forekomst af sygdommene, 1: en vægtet sum på 1, 2: en vægtet sum på 2 eller derover (Sundhedsdatastyrelsen, 2020). De sygdomsgrupper, der er inkluderet i Charlson komorbiditets indeks, er alvorlige sygdomme, men ikke nødvendigvis arbejdsrelateret sygdomme. Tidligere studier har vist, at især psykiske lidelser og sygdomme i bevægeapparatet, der i nogen grad stammer fra ens arbejdsliv, også har betydning for tidlig tilbagetrækning (Rice, Lang, Henley \& Melzer, 2011; van Rijn, Robroek, Brouwer \& Burdorf, 2014). Derfor konstrueres yderligere to indikatorer, der måler forekomsten af en række sygdomme i bevægeapparatet samt psykiske lidelser. Begge variable er dummy-variabler, der er lig 1 , hvis personen er diagnosticeret med mindst én sygdom i bevægeapparatet eller én psykisk lidelse. Sygdomme i bevægeapparatet inkluderer bl.a. diskusprolaps, slidgigt og nakke-skulder smerter, mens psykiske lidelser bl.a. inkluderer depression, nervøse og stress-relaterede tilstande samt udbrændthed (Dasam, 2020). Både Charlson komorbiditets indeks, sygdomme i bevægeapparatet og psykiske lidelser er målt ud fra diagnoser i Landspatientregistret, og derfor bliver diagnoserne først registreret, når en person har været indlagt på et sygehus eller får ambulant behandling på et sygehus. For imidlertid at indfange 'mindre' alvorlige sygdomme, der ikke kræver sygehuskontakt, anvendes derfor også antal kontakter til læge som fjerde indikator på helbred.
Helbred fra tidligere i livet måles som henholdsvis summen af Charlson komorbiditets indeks og kontakter hos læge samt forekomst af sygdomme i bevægeapparatet eller psykiske lidelser fra alderen 43-49 år. For helbred senere i livet måles de fire indikatorer for hvert år fra 50 år og til alderen for tidlig tilbagetrækning. Det bør i den forbindelse bemærkes, at de fire indikatorer for helbred ikke skal opfattes som selvstændige helbredsmål, men snarere som helbredsmål der komplementerer hinanden. De opfanger hver forskellige aspekter af helbred, men effekterne vil være korreleret.

Ud over de ovenstående variable inddrager analysen en række kontrol variable, som tidligere studier også har fundet påvirker tidlig tilbagetrækning. Dette inkluderer køn, hvor kvinder generelt trækker sig tidligere end mænd (Drobnič, 2002; Radl, 2013), partnerens arbejdsmarkedsstatus hvor personer med en partner, der har trukket sig tilbage, også selv er mere tilbøjelig til at trække sig tilbage (Friis, Ekholm, Hundrup, Obel \& Grønbaek, 2007; Radl \& Himmelreicher, 2015) samt etnisk oprindelse, hvor personer med ikke-vestlig baggrund i højere grad er på førtidspension og er arbejdsløse, men i mindre grad går på efterløn end personer med dansk baggrund (Danmarks Statistik, 2018).

\section{Analyse}

Første del af analysen er deskriptiv, og her anvendes såkaldte overlevelseskurver til at illustrere, om forskelle i tidlig tilbagetrækning mellem personer, der tilhører henholdsvis arbejderklassen og den højere serviceklasse, bliver større eller mindre jo tættere grupperne nærmer sig folkepensionsalderen. Overlevelseskurver stammer fra medicinsk forskning og anvendes til at måle levetiden til en bestemt hændelse som fx sygdom eller død indtræffer. I figur 1 måles 'levetiden' på arbejdsmarkedet fra alderen 50 år og frem til 
man trækker sig tilbage fra arbejdsmarkedet opdelt på social klasse. Y-aksen angiver sandsynligheden for at blive på arbejdsmarkedet for hvert år kohorten bliver ældre, og angiver dermed hvor stor en andel, der har forladt arbejdsmarkedet.

Figur 1. Overlevelseskurver for tidligt tilbagetrukne opdelt på social klasse, kohorten 1951

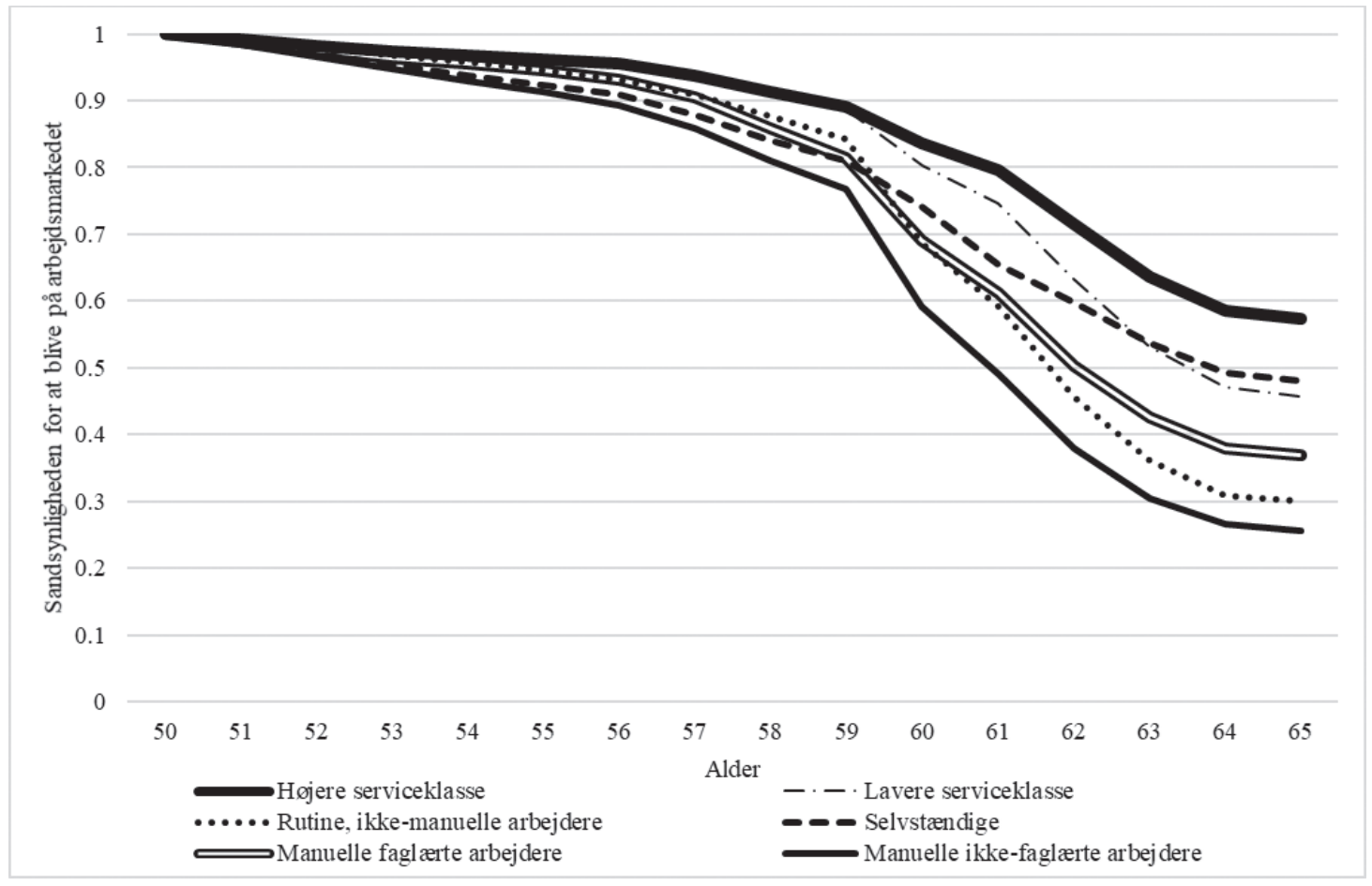

Figuren indikerer, at gabet mellem personer, der tilhører arbejderklassen og den højere serviceklasse, herunder særligt de manuelle ikke-faglærte arbejdere, overordnet set stiger, jo tættere kohorten nærmer sig folkepensionsalderen. Særligt bliver gabet udvidet ved 60-års alderen, hvor en stor andel af kohorten går på efterløn. Figuren viser, at ved alderen 61 år er 80\% af personer, der tilhører den højere serviceklasse, stadig på arbejdsmarkedet og dermed har 20\% forladt arbejdsmarkedet. For de manuelle ikke-faglærte arbejdere har ca. 50\% forladt arbejdsmarkedet og for de manuelle faglærte arbejdere er dette tal 40\% ved alderen 61. Ved alderen 62 har ca. 65\% af de manuelle ikke-faglærte arbejdere og $50 \%$ af de manuelle faglærte arbejdere forladt arbejdsmarkedet. Efter 62-års alderen ser gabet mellem personer, der tilhører arbejderklassen og den højere serviceklasse, ud til at stabilisere sig frem til folkepensionsalderen.

For at få et nærmere indblik i hvilke jobgrupper, som de ovenstående klasser bygger på, er klasserne opdelt i mindre jobgrupper i tabel 1. Tabellen præsenterer de jobgrupper inden for de enkelte klasser, hvor den største andel trækker sig. Selvstændige er ikke medtaget i tabel 1, da en del af dem ikke 
har DISCO-koder tilgængelige. Procenterne i parentes angiver hvor stor en andel, som jobgruppen udgør af alle de tidligt tilbagetrukne i den pågældende klasse.

Tabel 1. Top 3 jobgrupper der troekker sig tidligt opdelt på social klasse, kohorten 1951.

\begin{tabular}{|c|c|c|c|c|c|}
\hline & $\begin{array}{l}\text { Manuelle } \\
\text { ikke-faglærte } \\
\text { arbejdere }\end{array}$ & $\begin{array}{l}\text { Manuelle } \\
\text { faglærte } \\
\text { arbejdere }\end{array}$ & $\begin{array}{l}\text { Rutine, ik- } \\
\text { ke-manuelle } \\
\text { arbejdere }\end{array}$ & $\begin{array}{l}\text { Lavere } \\
\text { serviceklasse }\end{array}$ & $\begin{array}{l}\text { Højere } \\
\text { serviceklasse }\end{array}$ \\
\hline 1 & $\begin{array}{l}\text { Social- og } \\
\text { sundheds- } \\
\text { personale på } \\
\text { institutioner, } \\
\text { herunder pleje- } \\
\text { og omsorgs- } \\
\text { arbejde, samt } \\
\text { transport af } \\
\text { patienter } \\
(22 \%)\end{array}$ & $\begin{array}{l}\text { Tømrer og } \\
\text { snedkerarbejde } \\
(13 \%)\end{array}$ & $\begin{array}{l}\text { Alment kontor- } \\
\text { arbejde (17\%) }\end{array}$ & $\begin{array}{l}\text { Undervisning i } \\
\text { folkeskoler } \\
(29 \%)\end{array}$ & $\begin{array}{l}\text { Ledelse af } \\
\text { hoved- } \\
\text { aktiviteten i } \\
\text { virksomheder } \\
\text { med } 10 \\
\text { eller flere } \\
\text { beskæftigede } \\
(20 \%)\end{array}$ \\
\hline 2 & $\begin{array}{l}\text { Rengøring og } \\
\text { køkkenarbejde } \\
(15 \%)\end{array}$ & $\begin{array}{l}\text { Automekaniker } \\
\text { og auto- } \\
\text { montørarbejde } \\
(8 \%)\end{array}$ & $\begin{array}{l}\text { Kartoteks- } \\
\text { arbejde og } \\
\text { andre } \\
\text { specialopgaver, } \\
\text { ekskl. kunde- } \\
\text { betjening } \\
(13 \%)\end{array}$ & $\begin{array}{l}\text { Administrativt } \\
\text { arbejde, intern } \\
\text { sagsbehand- } \\
\text { ling, direktions- } \\
\text { sekretærarbej- } \\
\text { de, oversættelse } \\
\text { af korrespon- } \\
\text { dancer }(6 \%)\end{array}$ & $\begin{array}{l}\text { Arkitekt- } \\
\text { og ingeniør- } \\
\text { arbejde } \\
(17 \%)\end{array}$ \\
\hline 3 & $\begin{array}{l}\text { Andet arbejde* } \\
(12 \%)\end{array}$ & $\begin{array}{l}\text { Maskinelt } \\
\text { præcisions- } \\
\text { arbejde i metal } \\
\text { og indstilling } \\
\text { af metal- } \\
\text { forarbejde } \\
(7 \%)\end{array}$ & $\begin{array}{l}\text { Pædagogisk } \\
\text { arbejde med } \\
\text { børn under } \\
\text { den } \\
\text { undervisnings- } \\
\text { pligtige alder } \\
(10 \%)\end{array}$ & $\begin{array}{l}\text { Salgsarbejde, } \\
\text { eks. detailsalg } \\
(5 \%)\end{array}$ & $\begin{array}{l}\text { Ledelse i } \\
\text { offentlig } \\
\text { administration } \\
(8 \%)\end{array}$ \\
\hline
\end{tabular}

*Note: Andet arbejde doekker over manuelt ikke-fagloert arbejde, som ikke er kategoriseret.

For manuelle ikke-faglærte arbejdere er det især personer med arbejde indenfor social- og sundhedspersonale, pleje- og omsorgsarbejde samt rengørings- og køkkenarbejdere, der forlader arbejdsmarkedet tidligt. For de manuelle faglærte arbejdere er det især tømrere, snedkere, automekanikere og automontørarbejdere, der trækker sig tidligt. Blandt den lavere serviceklasse udgør folkeskolelærere $29 \%$ af alle dem, der forlader arbejdsmarkedet tidligt.

Det næste step af analysen består i at undersøge, hvad de langsigtede og kontemporære effekter af arbejdsløshed og helbred har af betydning for tidligere tilbagetrækning fra arbejdsmarkedet, herunder om disse faktorer 
kan forklare effekten af social klasse på tidligere tilbagetrækning. I denne del benyttes diskret-tid logit regressionsanalyse. Denne type regressionsanalyse tager højde for tidsstrukturen i datasættet og kan estimere sammenhængen mellem tidligere tilbagetrækning og en række forskellige variabler. Resultaterne er præsenteret i form af logit koefficienter. Hvis logit koefficienten er positiv, indikerer det, at den pågældende gruppe trækker sig tidligere tilbage fra arbejdsmarkedet sammenlignet med en referencegruppe. Hvis logit koefficienten er negativ, indikerer det, at gruppen trækker sig senere tilbage fra arbejdsmarkedet sammenlignet med referencegruppen. For at teste, om effekten af social klasse på risikoen for tidligere tilbagetræk- ning varierer over livsforløbet, indsættes et interaktionsled mellem social klasse og tiden (Allison, 2010). Idet personerne i denne analyse er fra samme årgang, er tiden lig med alder. I disse regressionsmodeller indikerer hovedleddene for de sociale klasser effekten af at tilhøre en bestemt klasse, når tiden er lig med 0 dvs. når personerne er 50 år gamle. Interaktionsleddene mellem de sociale klasser og tiden indikerer, i hvilken grad effekten af at tilhøre de sociale klasser bliver større eller mindre over tid. Hvis koefficienten for interaktionsleddet er positivt, indikerer det, at effekten bliver større over tid, og hvis den er negativ, indikerer det, at effekten bliver mindre over tid. Tabel 2 viser resultaterne af denne analyse.

Tabel 2. Diskret-tid logit modeller der estimerer risikoen for tidlig tilbagetraekning, kohorten 1951 (logit koefficienter).

\begin{tabular}{|c|c|c|c|}
\hline & Model 1 & Model 2 & Model 3 \\
\hline Lavere serviceklasse & $-0.273^{* * *}$ & $-0.316^{* * *}$ & $-0.317^{* * *}$ \\
\hline Rutine, ikke-manuelle arbejdere & -0.046 & $-0.155^{\star}$ & $-0.142^{* *}$ \\
\hline Selvstændige & $0.736^{* \star *}$ & $0.670^{* \star *}$ & $0.684^{* * *}$ \\
\hline Manuelle faglærte arbejdere & $0.461^{* * *}$ & $0.336^{* * *}$ & $0.330^{* * *}$ \\
\hline Manuelle, ikke-faglærte arbejdere & $0.546^{* * *}$ & $0.355^{\star * *}$ & $0.392^{* * *}$ \\
\hline Tid & $0.216^{\star \star \star}$ & $0.222^{\star \star \star}$ & $0.200^{\star * *}$ \\
\hline Tid $x$ Lavere serviceklasse & $0.056^{* * *}$ & $0.057^{* * *}$ & $0.056^{* * *}$ \\
\hline Tid x Rutine, ikke-manuelle arbejdere & $0.060^{* * *}$ & $0.066^{* * *}$ & $0.061^{* * *}$ \\
\hline Tid $\times$ Selvstændige & $-0.064^{* * *}$ & $-0.061^{* * *}$ & $-0.066^{* * *}$ \\
\hline Tid $\times$ Manuelle faglærte arbejdere & $0.013^{*}$ & $0.019 * *$ & $0.015^{*}$ \\
\hline
\end{tabular}

Fortsaettes på noeste side ... 


\begin{tabular}{|c|c|c|c|}
\hline Tid x Manuelle, ikke-faglærte arbejdere & $0.023^{* * *}$ & $0.033 * * *$ & $0.024 * * *$ \\
\hline Kvinde & $0.337^{* * *}$ & $0.232^{* \star *}$ & $0.267^{* * *}$ \\
\hline Partner i arbejde & $-0.225^{* * *}$ & $-0.159 * * *$ & $-0.111^{* * *}$ \\
\hline Partner arbejdsløs & -0.040 & 0.003 & 0.024 \\
\hline Partner tilbagetrukket & $0.250 * \star *$ & $0.306^{* * *}$ & $0.342^{\star * *}$ \\
\hline Ikke-vestlig oprindelse & $0.203^{* * *}$ & 0.019 & 0.054 \\
\hline Arbejdsløshed (43-49 år) & & $0.413^{* * *}$ & $0.201^{* * *}$ \\
\hline Charlson Komorbiditets Index 1 (43-49 år) & & $0.163^{* * *}$ & $0.118^{* * *}$ \\
\hline Charlson Komorbiditets Index 2+ (43-49 år) & & $0.144^{* * *}$ & $0.144^{\star * *}$ \\
\hline Sygdomme i bevægeapparatet (43-49 år) & & $0.083^{* * *}$ & $0.064^{* * *}$ \\
\hline Psykiske lidelser (43-49 år) & & $0.377^{* * *}$ & $0.314^{* * *}$ \\
\hline Kontakter til læge (43-49 år) & & $0.005^{\star * *}$ & $0.001^{*}$ \\
\hline Arbejdsløshed (50+ år) & & & $0.429 * * *$ \\
\hline Charlson Komorbiditets Index $1 \quad(50+$ år $)$ & & & $0.184^{* * *}$ \\
\hline Charlson Komorbiditets Index 2+ (50+ år) & & & $0.284^{* * *}$ \\
\hline Sygdomme i bevægeapparatet (50+ år) & & & $0.053^{* * *}$ \\
\hline Psykiske lidelser (50+ år) & & & $0.280^{* * *}$ \\
\hline Kontakter til læge (50+ år) & & & $0.003^{* * *}$ \\
\hline Observationer (år) & 637.063 & 637.063 & 637.063 \\
\hline
\end{tabular}

Note: Referencegrupperne er højere serviceklasse, mand, ingen partner, dansk eller anden vestlig oprindelse, Charlson Komorbiditets Index på 0, ingen sygdomme i bevaegeapparatet og ingen psykiske lidelser. ${ }^{*} p<0.05{ }^{* *} p<0.01{ }^{* * *} p<0.001$. 
Model 1 viser effekten af social klasse og interaktion mellem social klasse og tid på risikoen for tidlig tilbagetrækning, når der tages højde for køn, partners arbejdsmarkedsstatus og oprindelse. Ved baseline året som er alderen 50 år, er den estimerede koefficient (hovedleddet) for manuelle ikke-faglærte arbejdere sammenlignet med at tilhøre den højere serviceklasse på 0.546. Denne positive og signifikante koefficient indikerer således, at manuelle ikke-faglærte arbejdere forlader arbejdsmarkedet tidligere end personer, der tilhører den højere service klasse ved alderen 50 år. Interaktionsleddene mellem tiden og at tilhøre arbejderklassen er også positive og signifikante, hvilket indikerer, at der for denne gruppe er en mer-effekt på risikoen for tidlig tilbagetrækning for hvert år, de nærmer sig folkepensionsalderen sammenlignet med personer, der tilhører den højere serviceklasse. Ved alderen 60 år er den estimerede koefficient på $0.776(0.546+[10 * 0.023])$, hvilket svarer til en forskel på 35\%. Modellen viser altså, at effekten af at tilhøre arbejderklassen sammenlignet med den højere serviceklasse på risikoen for tidlig tilbagetrækning stiger, jo ældre kohorten bliver, hvilket bekræfter tendensen fra figur 1. Kontrolvariablene viser, at kvinder har større risiko for at trække sig tidligere tilbage end mænd, at have en partner, der har forladt arbejdsmarkedet, øger også risikoen for at trække sig tidligt tilbage sammenlignet med at have ingen partner, og endeligt har personer med ikke-vestlig oprindelse også større risiko for at forlade arbejdsmarkedet tidligt sammenlignet med personer med dansk eller anden vestlig oprindelse.

I model 2 er arbejdsløshed og helbred fra midt i livet (43-49 år) tilføjet for at undersøge de langsigtede effekter heraf. Alle fem indikatorer viser en positiv og signifikant sammenhæng, således at jo mere arbejdsløs og jo dårligere et helbred man har haft midt i livet, jo større er risikoen for tidlig tilbage- trækning. Kigger vi på effektstørrelserne på social klasse ved alderen 50 år, er de estimerede koefficienter for personer, der tilhører arbejderklassen, faldet fra model 1 til model 2. Dette indikerer, at tidligere arbejdsløshed og dårligt helbred fjerner noget af klasseforskellene i tidlig tilbagetrækning for baseline året (alder 50). Imidlertid fremgår det også af model 2, at mer-effekterne af at tilhøre arbejderklassen er blevet større i model 2 fra 0.023 til 0.033 for manuelle ikke-faglærte arbejdere $(\chi 2=538, \mathrm{P}<0.000)$ og fra 0.013 til 0.019 for manuelle faglærte arbejdere $(\chi 2=207, \mathrm{P}<$ 0.000). Dette indikerer, at klasseforskellene i tidlig tilbagetrækning er større over livsforløbet, når der kontrolleres for arbejdsløshed og helbred fra midt i livet. Selvom det ikke kan udelukkes, at dette resultat i nogen grad kan skyldes personlige karakteristika, som påvirker både arbejdsløsheds- og helbredshistorik og tidlig tilbagetrækning, indikerer det, at arbejdsløsheds- og helbredshistorik fra midt i livet formentligt har en langsigtet akkumuleret negativ effekt for personer, der tilhører arbejderklassen. Det er også værd at bemærke, at effekten af at have ikke-vestlig baggrund på risikoen for tidlig tilbagetrækning ikke længere er signifikant i model 2. Dette tyder på, at personer med ikke-vestlig baggrund i høj grad forlader arbejdsmarkedet tidligt, fordi de allerede midt i livet har oplevet arbejdsløshed og dårligt helbred.

I model 3 er indikatorerne, der måler arbejdsløshed og helbred umiddelbart inden tilbagetrækning tilføjet til modellen som tidsvarierende variable fra 50 år og opefter. Disse variable opfattes derfor som kontemporære frem for langsigtede, idet variablene er et mål for hvilken arbejdsløsheds- og helbredsstatus, som personerne i analysen har senere i livet og dermed umiddelbart inden de forlader arbejdsmarkedet. Her viser modellen for det første, at arbejdsløshed og dårligt helbred fra 50 år og frem til tilbagetrækning har positiv og signifikant sammenhæng med 
risikoen for tidligere tilbagetrækning. For det andet viser modellen, at arbejdsløshed og helbredsindikatorerne fra midt i livet (4349 år) stadig har en effekt på tidligere tilbagetrækning, om end effektstørrelserne er faldet lidt. Dette indikerer, at arbejdsløshed og dårligt helbred allerede fra midt i livet spiller en selvstændig rolle for risikoen for tidligere tilbagetrækning, også selvom der kontrolleres for arbejdsløshed og dårligt helbred senere i livet. Fx er antallet af lægebesøg fra midt i livet korrelereret med en risiko for tidlig tilbagetrækning, også selvom der kontrolleres for, at man med al sandsynlighed også aflægger flere lægebesøg senere i livet. Det fremgår også af model 3 , at effekten af social klasse ikke ændrer sig markant ved alderen 50 år sammenlignet med model 2 . Dette giver umiddelbart god mening, idet de tilføjede variabler måler arbejdsløshed og helbred fra alderen 50 år og opefter. Ser vi på mer-effekterne over tid i risikoen for tidlig tilbagetrækning for personer, der tilhører arbejderklassen, er disse effekter blevet mindre, når man kontrollerer for den kontemporære arbejdsløsheds- og helbredstilstand. Dette indikerer, at noget af den stigende klasseforskel over tid kan forklares af arbejdsløshed og helbred. Selvom der er kontrolleret for arbejdsløshed og helbred, er effekten af social klasse på tidligere tilbagetrækning stadig forholdsvis stor og signifikant, hvilket indikerer, at klasseforskellene i tidligere tilbagetrækning også bliver forklaret af andre faktorer.

\section{Diskussion og konklusion}

Denne artikel har undersøgt, hvordan forskelle i tidligere tilbagetrækning mellem personer, der tilhører henholdsvis arbejderklassen og den højere serviceklasse, udvikler sig over livsforløbet, og hvad de langsigtede og kontemporære effekter af arbejdsløshed og dårligt helbred er for risikoen for tidligere tilbagetrækning, herunder om disse faktorer kan forklare klasseforskellene i tidligere tilbagetrækning. Analysen har vist, at forskellen i tidligere tilbagetrækning mellem personer, der tilhører arbejderklassen og den højere serviceklasse, stiger over livsforløbet. Jo tættere kohorten nærmer sig folkepensionsalderen, desto større bliver forskellen i tidligere tilbagetrækning mellem klasserne. Således kan teorien om 'kumulativ stratifikation' genfindes i den empiriske analyse. Dette kan fortolkes som, at personer, der tilhører arbejderklassen tidligere i deres arbejdsliv, bliver eksponeret for risikofaktorer, der vedbliver med at forværre arbejdslivet. Omvendt ser personer, der tilhører den højere serviceklasse ud til at drage nytte af, at de har en række bedre arbejdsbetingelser og et bedre helbred, der ikke forværrer deres arbejdsliv. Bryder man kategorien af arbejderklassen op, er det især social- og sundhedspersonale, pleje- og omsorgsarbejdere samt tømrer og snedkere, der trækker sig tidligere tilbage fra arbejdsmarkedet.

Derudover viser analysen også, at arbejdsløshed og helbred fra midt i livet har betydning for risikoen for tidligere tilbagetrækning. De langsigtede effekter af arbejdsløshed og helbred fra midt i livet er stadig signifikante, når der kontrolleres for de kontemporære effekter af arbejdsløshed og helbred senere i livet. Det er ikke muligt på baggrund af de statistiske resultater alene at afdække mekanismerne bag disse effekter, men mulige tolkningerne på baggrund af eksisterende forskning kan være, at arbejdsløshed og dårligt helbred fra midt i livet kan påvirke andre faktorer, såsom personers holdninger til arbejde og fritid, risikovillighed og forestillinger om fremtiden, der har betydning for, om man forlader arbejdsmarkedet tidligt (DiPrete \& Eirich, 2006; Dupre, 2008; Raymo et al., 2011).

Ser man på hvor meget arbejdsløshed og helbred kan forklare klasseforskellene, forklarer de noget af effekterne, men ikke det 
hele. Givet at helbred er den største barriere i forhold til at forlade eller blive på arbejdsmarkedet (Edge et al., 2017), er det overraskende, at effekterne af social klasse ikke bliver forklaret mere af helbred. En årsag kan være, at de inkluderede helbredsmål er objektive mål, som baserer sig på kontaktforbrug i sundhedsvæsnet. Sammenligner man brugen af objektive og selvrapporterede mål for helbred, viser eksisterende forskning, at selvom de i det væsentligste afspejler den samme bagvedliggende faktor, kan anvendelsen af de to forskellige mål give forskellige resultater (Gupta, Adam \& McDade, 2010). Derudover viser eksisterende forskning også, at kontaktforbrug i sundhedsvæsnet varierer på tværs af køn (Bertakis, Azari, Helms, Callahan \& Robbins, 2000) og socioøkonomisk status (Field \& Briggs, 2001), hvilket også kan have påvirket analysens resultater. Endeligt kan den begrænsede effekt af helbred også skyldes, at personer, der tilhører arbejderklassen, vælger at trække sig tidligt, inden deres helbred udvikler sig i negativ retning og således også inden, de vælger at tage kontakt til sundhedsvæsnet.

\section{REFERENCER}

Allison, P. D. (2010). Survival Analysis Using SAS: A Practical Guide. Cary, North Carolina: SAS Institute Inc.

Bartley, M. (2004). Health Inequality. An Introduction to Theories, Concepts and Methods. Oxford: Polity Press.

Bertakis, K. D., Azari, R., Helms, L. J., Callahan, E. J. \& Robbins, J. A. (2000). Gender differences in the utilization of health care services. The Journal of Family Practice, 49(2), 147-52.

Birkelund, G. E., Heggebø, K. \& Rogstad, J. (2016). Additive or multiplicative disadvantage? The scarring effects of unemployment for ethnic minorities. European Sociological Review, 33(1). http://doi.org/10.1093/esr/jcw030
På trods af artiklens begrænsninger demonstrerer denne artikel, at en tidligere tilbagetrækning fra arbejdsmarkedet er forbundet med social ulighed. Artiklen demonstrerer at klasseforskellene i tidlig tilbagetrækning bliver større over livsforløbet, samt at tidlig tilbagetrækning er forbundet med faktorer, der ligger længere tilbage i ens arbejdsliv. Set i lyset af de allerede gennemførte og fremtidige reformer, der har til formål at begrænse tilgangen til tidlige tilbagetrækningsordninger samt at udskyde folkepensionsalderen, viser artiklen, at det ikke er alle seniorer, der kan respondere på disse tiltag, fordi seniorernes arbejdsliv allerede tidligt i livet former sig forskelligt. Dette betyder, at en forebyggende indsats for at få særligt personer, der tilhører arbejderklassen til at blive længere på arbejdsmarkedet, ikke kun skal være forbeholdt seniorer, men at indsatsen skal starte tidligere i arbejdslivet, særligt i forhold til de såkaldte push faktorer, som har langsigtede konsekvenser for, hvornår man forlader arbejdsmarkedet.

Blackwell, D. L., Hayward, M. D. \& Crimmins, E. M. (2001). Does childhood health affect chronic morbidity in later life? Social Science \& Medicine, 52(8), 1269-1284. http://doi. org/10.1016/S0277-9536(00)00230-6

Blossfeld, H.-P., Buchholz, S. \& Kurz, K. (Eds.). (2011). Aging Populations, Globalization and the Labor Market: Comparing Late Working Life and Retirement in Modern Societies. Cheltenham: Edward Elgar.

Charlson, M. E., Pompei, P., Ales, K. L. \& MacKenzie, C. R. (1987). A new method of classifying prognostic comorbidity in longitudinal studies: development and validation. Journal of Chronic Diseases, 40(5), 373-83. http://doi. org/10.1016/0021-9681(87)90171-8 
Damman, M., Henkens, K. \& Kalmijn, M. (2011). The impact of midlife educational, work, health, and family experiences on men's early retirement. The Journals of Gerontology Series B: Psychological Sciences and Social Sciences, 66B(5), 617-627. http://doi.org/10.1093/ geronb/gbr092

Danmarks Statistik. (2018). Indvandrere i Danmark 2018. København: Danmarks Statistik.

Dasam (2020). Diagnosekoder. Dansk selskab for arbejds- og miljømedicin. Tilgængelig på https://dasam.dk/kodning/diagnosekoder/. Besøgt 08-01-20

De Preter, H., Van Looy, D. \& Mortelmans, D. (2013). Individual and institutional push and pull factors as predictors of retirement timing in Europe: A multilevel analysis. Journal of Aging Studies, 27(4), 299-307. http://doi. org/10.1016/J.JAGING.2013.06.003

de Vaus, D. (2001). Research Design in Social Research. London: SAGE Publications.

DiPrete, T. A. \& Eirich, G. M. (2006). Cumulative advantage as a mechanism for inequality: A review of theoretical and empirical developments. Annual Review of Sociology, 32(1), 271-297. http://doi.org/10.1146/annurev. soc.32.061604.123127

Drobnič, S. (2002). Retirement timing in Germany. International Journal of Sociology, 32(2), 75-102. http://doi.org/10.1080/15579336.20 02.11770250

Dupre, M. E. (2008). Educational differences in health risks and illness over the life course: A test of cumulative disadvantage theory. Social Science Research, 37(4), 1253-1266. http://doi. org/10.1016/j.ssresearch.2008.05.007

Edge, C. E., Cooper, A. M. \& Coffey, M. (2017). Barriers and facilitators to extended working lives in Europe: a gender focus. Public Health Reviews, 38(2). http://doi.org/10.1186/s40985017-0053-8

Erikson, R. \& Goldthorpe, J. H. (1992). The Constant Flux: A Study og Class Mobility in Industrial Societies. Oxford: Clarendon Press.

Ferraro, K. F. \& Kelley-Moore, J. A. (2003). Cumulative Disadvantage and Health: Long-Term Consequences of Obesity? American Sociological Review, 68(5), 707-729.
Field, K. S. \& Briggs, D. J. (2001). Socio-economic and locational determinants of accessibility and utilization of primary health-care. $\mathrm{He}$ alth and Social Care in the Community, 9(5), 294-308. http://doi.org/10.1046/j.09660410.2001.00303.x

Friis, K., Ekholm, O., Hundrup, Y., Obel, E. \& Grønbaek, M. (2007). Influence of health, lifestyle, working conditions, and sociodemography on early retirement among nurses: The Danish Nurse Cohort Study. Scandinavian Journal of Public Health, 35(1), 23-30. http:// doi.org/10.1080/14034940600777278

Gangl, M. (2006). Scar effects of unemployment: an assessment of institutional complementarities. American Sociological Review, 71(6), 986-1013. http://doi.org/10.1177/000312240607100606

Ganzeboom, H. B. G. \& Treiman, D. J. (1996). Internationally comparable measures of occupational status for the 1988 international standard classification of occupations. Social Science Research, 25(3), 201-239.

Gupta, S., Adam, E. \& McDade, T. (2010). Objective versus Subjective Measures of Health: Systematic differences, determinants and biases. Preliminary version. (https://pdfs.semanticscholar.org/7174/b7014941dc2bab59c1125b2ab4183c8b658c.pdf)

Hansen, H.-T. \& Ingebrigtsen, T. (2008). Social class and sickness absence in Norway. Acta Sociologica, 51(4), 309-327. http://doi. org/10.1177/0001699308097376

Jacobs, S. C. (2002). Reliability and recall of unemployment events using retrospective data. Work, Employment and Society, 16(3), 537-548. http://doi.org/10.1177/095001702762217489

Jensen, P. H. (2011). Aldring og arbejde - en begrebsramme. In J. G. Andersen \& P. H. Jensen (Eds.), Tilbagetraekning fra arbejdsmarkedet årsager og effekter (pp. 35-56). Frederiksberg: Frydenlund.

Kohli, M. \& Rein, M. (1991). The changing balance of work and retirement. In M. Kohli, M. Rein, A.-M. Guillemard \& H. Van Gunsteren (Eds.), Time for Retirement: Comparative Studies of Early Exit from the Labor Force (pp. 1-35). Cambridge: Cambridge University Press. 
Krokstad, S., Johnsen, R. \& Westin, S. (2002). Social determinants of disability pension: a 10-year follow-up of 62000 people in a Norwegian county population. International Journal of Epidemiology, 31(6), 1183-1191. http://doi. org/10.1093/IJE/31.6.1183

Leinonen, T., Chandola, T., Laaksonen, M. \& Martikainen, P. (2018). Socio-economic differences in retirement timing and participation in post-retirement employment in a context of a flexible pension age. Ageing \& Society, 1-21. http://doi.org/10.1017/S0144686X18000958

Lund, T. \& Villadsen, E. (2005). Who retires early and why? Determinants of early retirement pension among Danish employees 57-62 years. European Journal of Ageing, 2(4), 275-280. http://doi.org/10.1007/s10433-0050013-X

Lynch, S. M. \& Brown, J. S. (2011). Stratification and Inequality Over the Life Course. Handbook of Aging and the Social Sciences, 105-117. http://doi.org/10.1016/B978-0-12380880-6.00008-3

Nilsen, Ø. A. \& Reiso, K. H. (2011). Scarring effects of unemployment (Discussion Papers No. 26). Discussion Papers. Bergen. http://doi. org/10.2139/ssrn.1972294

O'Rand, A. M. \& Henretta, J. C. (1999). Age and Inequality. Colorado/Oxford: Westview Press.

Radl, J. (2013). Labour market exit and social stratification in Western Europe: The effects of social class and gender on the timing of tetirement. European Sociological Review, 29(3), 654-668. http://doi.org/10.1093/esr/jcs045

Radl, J. \& Himmelreicher, R. K. (2015). The influence of marital status and spousal employment on retirement behavior in Germany and Spain. Research on Aging, 37(4), 361-87. http://doi. org $/ 10.1177 / 0164027514536403$

Raymo, J. M., Warren, J. R., Sweeney, M. M., Hauser, R. M. \& Ho, J.-H. (2011). Precarious employment, bad jobs, labor unions, and early retirement. The Journals of Gerontology
Series B: Psychological Sciences and Social Sciences, 66B(2), 249-259. http://doi.org/10.1093/ geronb/gbq106

Rice, N. E., Lang, I. A., Henley, W. \& Melzer, D. (2011). Common health predictors of early retirement: findings from the English Longitudinal Study of Ageing. Age and Ageing, 40(1), 54-61. http://doi.org/10.1093/ageing/afq153 Solinge, H. Van \& Henkens, K. (2018). Work-related factors as predictors in the retirement decision-making process of older workers in the Netherlands. http://doi.org/10.1017/ S0144686X13000330

Sundhedsdatastyrelsen (2020). Borgere med KOL - kontaktforbrug i sundhedsvoesenet og medicinforbrug. København: Sundhedsdatastyrelsen Tilgængelig på https://sundhedsdatastyrelsen. $\mathrm{dk} / \mathrm{da} /$ tal-og-analyser/analyser-og-rapporter/ sygdomme/kronisk_obstruktiv_lungesygdom. Besøgt 08-01-20

Thorsen, S. V., Jensen, P. H. \& Bjørner, J. B. (2016). Psychosocial work environment and retirement age: a prospective study of 1876 senior employees. International Archives of Occupational and Environmental Health, 89(6), 891-900. http://doi.org/10.1007/s00420-016-1125-7

van Rijn, R. M., Robroek, S. J. W., Brouwer, S. \& Burdorf, A. (2014). Influence of poor health on exit from paid employment: a systematic review. Occupational and Environmental Medicine, 71(4), 295-301. http://doi.org/10.1136/ oemed-2013-101591

Visser, M., Gesthuizen, M., Kraaykamp, G. \& Wolbers, M. H. J. (2016). Inequality among older workers in the Netherlands: A life course and social stratification perspective on early retirement. European Sociological Review, 32(3), 370-382. http://doi.org/10.1093/esr/jcw013 Wang, M. \& Shultz, K. S. (2010). Employee Retirement: A Review and Recommendations for Future Investigation. Journal of Management, 36(1), 172-206. http://doi. org/10.1177/0149206309347957

Jeevitha Yogachandiran Qvist, cand.scient.soc., ph.d.-stipendiat Institut for Politik og Samfund, Aalborg Universitet

e-mail: jy@dps.aau.dk 